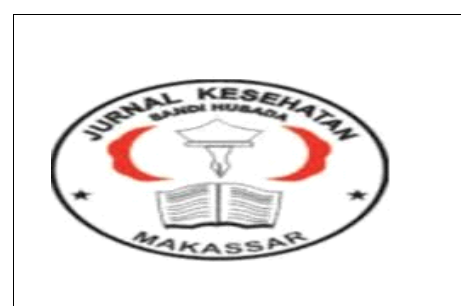

Jurnal IImiah Kesehatan Sandi Husada

hhttps://akper-sandikarsa.e-journal.id/JIKSH

Vol 11, No, 1, Juni 2020, pp;305-312

p-ISSN: 2354-6093 dan e-ISSN: 2654-4563

DOI: $10.35816 /$ jiskh.v10i2.275

\title{
Studi Faktor Risiko Kelainan Miopia Di Rumah Sakit Pertamina Bintang Amin
}

Risk Factors for Myopia Abnormalities at the Bintang Amin Pertamina Hospital

\author{
Titi Lestari ${ }^{1}$, Anggunan ${ }^{2}$, Tusy Triwahyuni ${ }^{3}$, Rachmat Syuhada ${ }^{4}$ \\ IIlmu Kedokteran universitas Malahayati \\ 23 IIlmu kedokteran umum universitas Malahayati
}

\begin{tabular}{l}
\hline \multicolumn{1}{c}{ Artikel info } \\
\hline \\
Artikel history: \\
Received; 10 April 2020 \\
Revised:14 April 2020 \\
Accepted;22 April 2020
\end{tabular}

\begin{abstract}
Abstrak
Latar belakang: Penglihatan merupakan indera yang sangat penting dalam menentukan kualitas hidup manusia. Dalam penglihatan, mata mempunyai berbagai macam kelainan refraksi salah satunya miopia. Miopia atau rabun jauh merupakan keadaan dimana cahaya yang memasuki mata terfokus di depan retina sehingga membuat objek yang jauh terlihat kabur. Banyak faktor yang menyebabkan miopia atau rabun jauh yaitu usia, jenis kelamin, keturunan, dan aktivitas jarak dekat.Tujuan penelitian: Untuk mengetahui faktor risiko kelainan miopia di rumah sakit pertamina bintang amin provinsi lampung tahun 2020.Metode penelitian: Jenis penelitian ini adalah deskriptif dengan desain kuantitatif. Sampel pada penelitian ini sebanyak 65 orang dengan teknik total sampling.pengambilan data menggunakan lembar kuesioner dan wawancara. teknik analisa data menggunakan analisis univariat untuk mengetahui distribusi frekuensi faktor risiko miopia. Hasil penelitian: Hasil penelitian ini menunjukan bahwa paling banyak dijumpai pada frekuensi miopia ringan sebanyak 39 orang $(60,0 \%)$. Frekuensi faktor usia dewasa muda sebanyak 42 responden $(64,6 \%)$. Frekuensi faktor jenis kelamin perempuann sebanyak 37 responden (56,9\%). Frekuensi faktor riwayat keturunan ayah/ibu saja sebanyak 28 responden (43,1\%). Frekuensi faktor aktivitas jarak dekat bermain komputer, Hp selama 1-2 jam sebanyak 28 orang (43,1\%), membaca buku selama 1-2 jam sebanyak 39 orang (60,0\%), dan menonton TV selama 1-2 jam sebanyak 50 orang $(76,9 \%)$. Kesimpulan: Terdapat faktor risiko miopia antara lain usia, jenis kelamin, keturunan, dan aktivitas jarak dekat.

Abstract

Background: Vision is a very important sense in determining the
\end{abstract}

Titi Lestari, eatall, Risk Factors for Myopia Abnormalities at the Bintang Amin Pertamina Hospital, jiksh Vol.11 No. 1 Juni 2020 
quality of human life. In the vision, the eye has a variety of refractive disorders, one of which is myopia. Myopia or nearsightedness is a condition where light entering the eye is focused in front of the retina, making distant objects appear blurred. Many factors cause myopia or nearsightedness, namely age, gender, heredity, and short distance activity. Research Purpose: To determine the risk factors of myopia in Pertamina Bintang Amin Hospital in Lampung Province in 2020. Research Method: This type of research is descriptive quantitative design. The sample in this study were 65 people with a total sampling technique. Data collection using questionnaire sheets and interviews. Data analysis techniques used univariate analysis to determine the frequency distribution of myopia risk factors. Research Result: The results of this study showed that the most common frequency of mild myopia was 39 people (60.0\%). The frequency factor of young adult age was 42 respondents (64.6\%). The frequency of female gender factors was 37 respondents (56.9\%). The frequency of historical factors father/mother's descendants alone were 28 respondents (43.1\%). Frequency factors of close-range activity playing computer, cellphone for 12 hours as many as 28 people (43.1\%), reading books for 1-2 hours as many as 39 people (60.0\%), and watching TV for 1-2 hours as much 50 people (76.9\%). Conclusion: there is a risk factor of myopia including age, sex, heredity, and close-range activity.

Keywords:

Faktor risiko;

Miopia;
Coresponden author:

Email: $\underline{\text { hariyatilestari27@gmail.com }}$

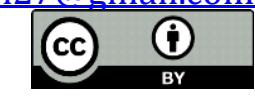

artikel dengan akses terbuka dibawah lisensi CC BY -4.0

\section{Pendahuluan}

Penglihatan merupakan indera yang sangat penting dalam menentukan kualitas hidup manusia. Indera penglihatan yang dimaksud adalah mata. Tanpa mata, manusia mungkin tidak dapat melihat sama sekali apa yang disekitarnya. Dalam penglihatan, mata mempunyai berbagai macam kelainan refraksi. Kelainan refraksi tersebut antara lain seperti miopia, presbiopia, hipermetropia dan afakia (World Health Organization, 2012).Miopia atau biasa disebut Rabun Jauh merupakan suatu kondisi dimana cahaya yang memasuki mata terfokus di depan retina sehingga membuat objek yang jauh terlihat kabur (James, Chew, \& Bron, 2006). Menurut derajat beratnya, miopia dibagi dalam tiga kriteria yaitu ringan, sedang, dan berat (Ilyas, 2010).

Dalam hal ini gejala miopia yaitu kelainan pada jarak pandang, dan untuk penderita dengan miopia ringan dapat diketahui dengan pemeriksaan visus mata (Israr \& Yayan, 2010). Miopia bersifat progresif pada masa anak-anak dan cenderung stabil ketika mereka mencapai usia 20 tahun atau akhir remaja (Hartanto \& Inakawati, 2010). Pada miopia atau penglihatan dekat, sewaktu otot siliaris relaksasi total, cahaya dari objek jauh difokuskan di depan retina. 
Keadaan ini biasanya akibat bola mata terlalu panjang, tetapi dapat juga disebabkan daya bias system lensa terlalu kuat.

Miopia merupakan masalah kesehatan masyarakat yang cukup menonjol dan merupakan penyebab utama kelainan penglihatan di dunia. Kelainan ini terdapat pada 25\% penduduk di Amerika dan presentase lebih tinggi didapatkan di Asia, yang bahkan mencapai 70\%-90\% populasi di berbagai Negara Asia. Prevalensi miopia di Eropa sebesar 30\%-40\% dan di Afrika 10\%-20\% (Basri, 2014).

Menurut Khishnaiah (2009) banyak faktor yang memengaruhi miopia. Faktor internal yang diduga menyebabkan miopia diantaranya usia, jenis kelamin, riwayat kelahiran, keturunan, etnik, genetik, status gizi, merokok, serta menderita penyakit tertentu seperti hipertensi dan diabetes melitus (DM). Sedangkan faktor ekstrinsik yang diduga berkaitan dengan miopia adalah lama beraktivitas dekat dan jauh, lokasi tempat tinggal, tingkat pendidikan dan IQ sosioekonomi. Miopia yang terjadi sebelum usia 20 tahun akan menetap. Sementara itu, kejadian miopia yang muncul setelah usia 20 tahun biasanya disebabkan oleh komplikasi penyakit seperti hipertensi dan DM (Khishnaiah, Marmamula, \& Rohit, 2009). Penelitian untuk mengetahui faktor risiko miopia dapat dilakukan sebelum usia 18-20 tahun karena kemunculan miopia pada usia 15-17 tahun (usia rata- rata siswa SMA) akan menetap untuk selanjutnya. Jika penelitian dilakukan pada usia yang terlalu muda ( $<15$ tahun) maka dikhawatirkan insiden miopia belum muncul secara sempurna.

\section{Metode}

Jenis penelitian ini adalah Deskriptif dengan desain kuantitatif, subjek peneliti adalah seluruh pasien dengan kelainan miopia. Tempat penelitian ini dilaksanakan di Rumah Sakit Pertamina Bintang Amin (RSPBA). Waktu penelitian ini di laksanakan pada (bulan Februari-Maret 2020).Cara penelitian ini adalah mengumpulkan data primer dengan menggunakan lembar kuesioner, yaitu data yang didapat langsung dari responden.Penelitian ini dilakukan pada pasien di poli mata RSPBA yang sudah melakukan pemeriksaan dan terdiagnosis miopia, dan berusia 15 sampai dengan 60 tahun dengan alasan pada umur tersebut responden mampu menggambarkan hal yang sebenarnya tentang kelainan miopia yang dialaminya. Jumlah sampel yang digunakan sebanyak 65 responden dengan pengambilan secara accidental sampling, variabel independen pada penelitian ini adalah usia, jenis kelamin, keturunan dan aktivitas jarak dekat.

\section{Hasil Dan Pembahasan}

Tabel 1. Distribusi Frekuensi Kelainan Miopia

\begin{tabular}{lll}
\hline Miopia & Frekuensi & Persentase (\%) \\
\hline Miopia Ringan & 39 & 60,0 \\
\hline Miopia Sedang & 24 & 36,9 \\
\hline Miopia Berat & 2 & 3,1 \\
\hline Total & 65 & 100
\end{tabular}

Sumber: data primer diolah 2020

Titi Lestari, eatall, Risk Factors for Myopia Abnormalities at the Bintang Amin Pertamina Hospital, jiksh Vol.11 No. 1 Juni 2020 
Tabel 2. Distribusi Frekuensi Usia

\begin{tabular}{lll}
\hline Usia & Frekuensi (orang) & Persentase (\%) \\
\hline Remaja & 4 & 6,2 \\
\hline Dewasa Muda & 42 & 64,6 \\
\hline DewasaTua & 19 & 29,2 \\
\hline Total & 65 & 100
\end{tabular}

Sumber: data primer diolah 2020

Tabel 3. Distribusi Frekuensi Jenis Kelamin

\begin{tabular}{lcl}
\hline JenisKelamin & Frekuensi & Persentase(\%) \\
\hline Laki-laki & 28 & 43,1 \\
\hline Perempuan & 37 & 56,9 \\
\hline Total & 65 & 100 \\
Sumber: data primer diolah 2020 &
\end{tabular}

Tabel 4. Distribusi Frekuensi Keturunan

\begin{tabular}{lll}
\hline Riwayat Keturunan & Frekuensi & Persentase(\%) \\
\hline Tidak ada & 15 & 23,1 \\
\hline Ayah/ibu saja & 28 & 43,1 \\
\hline Kedua orang tua & 22 & 33,8 \\
\hline Total & 65 & 100 \\
\hline
\end{tabular}

Sumber: data primer diolah 2020

Tabel 5. Distribusi Frekuensi Aktivitas jarak dekat

\begin{tabular}{lll}
\hline Bermain Komputer, Hp & Frekuensi & Persentase(\%) \\
\hline$<1$ jam & 18 & 27,7 \\
\hline $1-2$ jam & 28 & 43,1 \\
\hline$>2$ jam & 19 & 29,2 \\
\hline Total & 65 & 100 \\
\hline Membaca Buku & Frekuensi & Persentase(\%) \\
\hline$<1$ jam & 20 & 30,8 \\
\hline $1-2$ jam & 39 & 60,0 \\
\hline$>2$ jam & 6 & 9,2 \\
\hline Total & 65 & 100 \\
\hline Menonton Tv & Frekuensi & Persentase(\%) \\
\hline$<1$ jam & 12 & 18,5 \\
\hline $1-2$ jam & 50 & 76,9 \\
\hline$>2$ jam & 3 & 4,6 \\
\hline Total & 65 & 100 \\
\hline
\end{tabular}

Sumber: data primer diolah 2020

\section{Distribusi Frekuensi Kelainan Miopia}

Menunjukkan bahwa responden paling banyak dengan miopia ringan sebanyak 39 orang $(60,0 \%)$. Pada penelitian di dapatkan responden dengan miopia ringan memakai kaca mata dengan rata-rata dioptri 1-2 dioptri, dan kesadaran kesehatan dari responden dengan miopia ringan sangat berpengaruh terhadap risiko miopia yang berat sehingga mereka selalu konsultasi dengan dokter. Berbeda dengan responden dengan miopia berat, di lihat dari faktor aktivitas jarak dekat, mata bekerja tidak terlalu berlebih atau terlalu lama, namun dengan 
membiarkan terus-menerus dan tidak di konsultasikan dengan dokter, hal ini lah yang mungkin menimbulkan risiko yang tinggi untuk terkena miopia berat.

Hasil penelitian ini sejalan dengan sebuah penelitian pada mahasiswa pendidikan dokter FK Unand tahun 2018.Diketahui pada penelitian tersebut paling banyak terdapat miopia ringan pada mahasiswa dengan jumlah 93 orang dari total sampel 121 orang (Mutia, 2018). Hal ini sesuai dengan literatur bahwa pada individu tanpa faktor predisposisi miopia yang terpajan faktor miopigenik secara terus menerus (misalnya kerja jarak dekat) pada akhirnya dapat mengalami miopia ringan.Faktor risiko pada miopia ringan meliputi faktor genetik dan lingkungan, faktor lingkungan merupakan kebiasaan melihat atau membaca dekat, kurangnya aktivitas luar rumah, dan tingkat pendidikan yang lebih tinggi (Fredick, 2014).

\section{Distribusi Frekuensi Usia Dengan Kelainan Miopia}

Menunjukkan bahwa responden paling banyak dengan kelainan miopia ber usia dewasa muda sebanyak 42 orang (64,6\%). Dikatakan usia dewasa muda adalah usia 21 tahun sampai dengan usia 40 tahun. Pada usia dewasa miopia biasanya menetap dan jika pada usia tua biasanya sering terdapat penurunan prevalensi miopia menjadi hipermetropia atau rabun dekat (kesulitan membaca dengan jarak dekat). Miopia pada usia anak-anak bisa saja terjadi namun kemunculan miopia pada usia anak belum menetap dikarenakan pertumbuhan bola mata masih dapat berubah.

Hasil penelitian ini sejalan dengan sebuah penelitian di Makassar, Sulawesi Selatan, pada tahun 2019. Diketahui dalam penelitian tersebut kejadian miopia banyak di alami pada usia dewasa muda (Dyatmika \& Dhany, 2009). Suatu teori menjelaskan bahwa prevalensi miopia pada orang dewasa disebabkan oleh perubahan indeks refraksi lensa yaitu indeks refraksi lensa meningkat dengan meningkatnya kekeruhan inti lensa hal ini dikarenakan perubahan komponen bola mata yang pada akhirnya akan mengakibatkan perubahan status refraksi menjadi miopia (Della, 2014). Faktor usia dengan miopia berkaitan dengan kekuatan akomodasi yang akan meningkat sesuai dengan kebutuhan sehingga semakin dekat benda yang dilihat makin kuat mata berakomodasi, akomodasi semakin menurun dengan bertambahnya usia (Lieberman, 2013b).

\section{Distribusi Frekuensi Jenis Kelamin Dengan Kelainan Miopia}

Berdasarkan tabel 4.3 dari 65 responden menunjukkan bahwa responden paling banyak dengan kelainan miopia berjenis kelamin perempuan sebanyak 37 orang (56,9\%). Pada penelitian ini didapatkan jenis kelamin perempuan lebih banyak mengalami miopia dibanding laki-laki. Perempuan yang mengalami miopia dikarenakan pola hidup dan lingkungan yang jarang terkena sinar matahari. Sinar matahari sendiri dibutuhkan untuk daya akomodasi mata dan refraksi cahaya pada retina. Dengan sinar matahari, mata mendapatkan sinar yang cukup untuk melatih daya tangkap bayangan yang akan dipantulkan.

Menurut Penelitian yang menyatakan bahwa pelajar perempuan lebih banyak ditemui menderita miopia.Hal ini dikarenakan wanita memiliki aktifitas diluar ruangan yang lebih sedikit dibandingkan laki-laki, sehingga perempuan memiliki risiko miopia lebih besar daripada laki-laki.Aktivitas yang dilakukan diluar ruangan seperti olahraga dapat memberikan intensitas cahaya yang lebih banyak sehingga mengurang daya akomodasi dan mengurang pelepasan dopamin oleh retina untuk mengurangi elongasi mata, sehingga dapat menurunkan risiko miopia (Rose et al., 2018).

Penelitian ini sejalan dengan sebuah penelitian di Bandar Lampung, pada tahun 2019.Dalam

Titi Lestari, eatall, Risk Factors for Myopia Abnormalities at the Bintang Amin Pertamina Hospital, jiksh Vol.11 No. 1 Juni 2020 
penelitian tersebut juga terdapat jenis kelamin perempuan lebih banyak menderita miopia dibanding dengan jenis kelamin laki-laki (Eksa, 2019).

\section{Distribusi Frekuensi Keturunan Dengan Kelainan Miopia}

Berdasarkan tabel 4.4 dari 65 responden menunjukkan bahwa responden dengan kelainan miopia paling banyak faktor keturunan dari ayah/ ibu saja sebanyak 28 orang $(43,1 \%)$. Anak yang memilki orangtua yang menderita kelainan miopia memang cenderung untuk terkena miopia hal ini disebabkan oleh karena regenerasi gen yang dibawakan oleh orangtua ke anak sehingga mengakibatkan bentuk bola mata menjadi lebih lonjong dan memiliki sumbu aksial yang lebih panjang. Biasanya orangtua yang mengalami miopia cenderung menerapkan kebiasaan yang dilakukan dalam sehari-hari yang berakibat terjadinya miopia pada anaknya.

Hasil penelitian ini sejalan dengan sebuah penelitian di Sumatera Barat, pada tahun 2017.Penelitian tersebut didapatkan bahwa paling banyak terdapat faktor riwayat keturunan dari salah satu orangtua (Fivi, 2017). Faktor risiko yang penting dari miopia adalah faktor keturunan. Orangtua yang miopia cenderung memiliki anak miopia. Jika kedua orangtua miopia, maka risiko anak mengalami miopia akan semakin besar. Prevalensi miopia 33-60\% pada anak dengan kedua orang tua miopia.Pada anak yang memiliki salah satu orang tua miopia prevalensinya $23-40 \%$ dan hanya $6-15 \%$ anak mengalami miopia yang tidak memiliki orang tua miopia (Yingyong, 2012).

Faktor genetik, yang digambarkan dengan adanya riwayat keturunan, merupakan faktor yang paling mempengaruhi terjadinya miopia. Diketahui bahwa miopia terjadi akibat pemanjangan sumbu horizontal bola mata, sehingga bayangan jatuh di depan retina. Patogenesis abnormalitas sumbu horizontal bola mata ini hanya dapat dijelaskan oleh adanya kelainan di tingkat genetik. Terdapat 18 lokus gen pada 15 kromosom yang diduga berperan terhadap terjadinya miopia. Meskipun demikian, seluruh lokus tersebut tidak terbukti secara langsung menyebabkan miopia (Jacobi \& Pusch, 2010).

\section{Distribusi Frekuensi Aktivitas Jarak Dekat Dengan Kelainan Miopia}

Menunjukkan bahwa responden dengan kelainan miopia paling banyak didapatkan aktivitas jarak dekat bermain komputer, Hp selama 1-2 jam sebanyak 28 orang $(43,1 \%)$. Membaca buku selama 1-2 jam sebanyak 39 orang (60,0\%). Dan menonton Tv selama 1-2 jam sebanyak 50 orang $(76,9 \%)$.

Aktivitas jarak dekat paling banyak dilakukan oleh responden pada penelitian ini selama 1-2 jam. Dalam aktivitas aktivitas jarak dekat, otot mata berperan dalam membantu mata bekerja, Jika aktivitas jarak terlalu dekat antara mata dengan objek dengan waktu yang lama maka akan mengakibatkan otot mata cepat lelah. Kondisi mata yang lelah dan terus menerus seperti itu maka mata akan terbiasa bekerja hanya dengan jarak yang dekat. Sehingga ketika melihat objek yang jauh mata akan terasa kabur. Dalam penelitian ini terdapat adanya keterkaitan dengan pekerjaan. Pekerjaan pada responden banyak didapatkan sebagai karyawan kantor dimana dalam pekerjaan mereka sering menggunakan aktivitas jarak dekat sebagai media yang mempermudah untuk mengakses informasi dan media komunikasi seperti bermain komputer, laptop ataupun handphone. Mata yang bekerja terlalu lama akan mengakibatkan otot mata menjadi lemah sehingga dapat mengurangi ketajaman penglihatan pada responden.

Hasil tersebut sejalan dengan penelitian sebelumnya yang dilakukan di Fakultas Kedokteran Universitas Lampung, pada tahun 2018. Penelitian tersebut juga menyimpulkan bahwa aktivitas melihat dekat merupakan salah satu komponen dari faktor lingkungan yang terbukti

Titi Lestari, eatall, Risk Factors for Myopia Abnormalities at the Bintang Amin Pertamina Hospital, jiksh Vol.11 No. 1 Juni 2020 
berhubungan dengan kejadian miopia, hasil penelitian ini juga mendapati subjek penelitian melakukan lama aktivitas jarak dekat selama 1-2 jam (76,9\%) (Sukamto, 2018).

Terdapat teori yang menyatakan bahwa faktor gaya hidup yaitu aktivitas melihat dekat yang terlalu banyak, seperti membaca buku, menonton TV, melihat layar komputer, bermain video game yang terlalu lamadapat menyebabkan melemahnya otot siliaris mata sehingga mengakibatkan gangguan otot untuk melihat jauh. Aktivitas melihat dekat terus menerus, terutama pada usia anak-anak dan remaja, akan menyebabkan perkembangan mata menjadi tidak normal (Lieberman, 2013a). Hal ini menyebabkan sumbu horizontal mata menjadi lebih panjang dari pada normal. Melakukan aktivitas jarak dekat telah menjadi salah satu jenis aktivitas yang memiliki proporsi tinggi pada masyarakat saat ini.Hal ini disebabkan semakin luasnya penggunaan smartphone yang dapat digunakan untuk berbagai keperluan, seperti membaca, menonton video, dan komunikasi.

\section{Simpulan Dan Saran}

Berdasarkan hasil dan pembahasan penelitian tentang studi faktor risiko kelainan miopia di Rumah Sakit Pertamina Bintang Amin Provinsi Lampung tahun 2020 dapat di ambil kesimpulan sebagai berikut;

1. Diketahui distribusi frekuensi miopia pada penelitian paling banyak dijumpai pada frekuensi miopia ringan sebanyak 39 orang $(60,0 \%)$.

2. Diketahui distribusi frekuensi faktor usia dengan kelainan miopia pada penelitian paling banyak dijumpai pada kelompok usia dewasa muda sebanyak 42 responden $(64,6 \%)$.

3. Diketahui distribusi frekuensi faktor jenis kelamin dengan kelainan miopia pada penelitian paling banyak dijumpai pada kelompok jenis kelamin perempuann sebanyak 37 responden $(56,9 \%)$.

4. Diketahui distribusi frekuensi faktor riwayat keturunan dengan kelainan miopia pada penelitian paling banyak dijumpai pada kelompok riwayat keturunan ayah/ibu saja sebanyak 28 responden $(43,1 \%)$.

5. Diketahui distribusi frekuensi faktor aktivitas jarak dekat dengan kelainan miopia pada penelitian paling banyak dijumpai bermain komputer, Hp selama 1-2 jam sebanyak 28 orang (43,1\%), membaca buku selama $1-2$ jam sebanyak 39 orang $(60,0 \%)$, dan menonton Tv selama 1-2 jam sebanyak 50 orang $(76,9 \%)$.

Melihat banyaknya penderita miopia disarankan menambahkan penelitian ini sebagai landasan teori saat memberikan edukasi kepada pasien berkaitan dengan kelainan miopia. Disarankan batasi lama aktivitas jarak dekat karena penelitian ini membuktikan bahwa aktivitas jarak dekat berhubungan dengan kelainan miopia.Mempertimbangkan melakukan pemeriksaan refraksi secara langsung untuk menentukan status miopia dan bukan hanya menggunakan kuesioner agar hasil yang didapatkan lebih akurat.

Titi Lestari, eatall, Risk Factors for Myopia Abnormalities at the Bintang Amin Pertamina Hospital, jiksh Vol.11 No. 1 Juni 2020 


\section{Daftar Rujukan}

Basri, S. (2014). Etiopatogenesis dan Penatalaksanaan Miopia pada Anak Usia Sekolah. Jurnal Kedokteran Syiah Kuala.

Della, B. (2014). Prevalensi Miopia pada Usia Dewasa. Jurnal Kedokteran Syiah Kuala, 15(2), 108.

Dyatmika, D., \& Dhany, K. (2009). Hubungan antara Pendidikan, Seks, dan Usia dengan Kelainan Refraksi di RSU DR. Wahidin Soedirohusodo. Jurnal Ilmiah Kedokteran Wijaya Kusuma, 8.

Eksa, D. (2019). Pengaruh Aktivitas Melihat Jarak Dekat Terhadap Angka Kejadian Miopia Pada Mahasiswa Fakultas Kedokteran Universitas Malahayati. E-Journal Universitas Malahayati.

Fivi, S. (2017). Hubungan Faktor Keturunan Dan Gaya Hidup Dengan Kejadian Miopia Pada Anak Usia Sekolah Di Balai Kesehatan Indera Masyarakat Sumatera Barat Tahun 2017.

Fredick, D. (2014). Miopia clinical review. Br Med J, 324(7347), 1195-1199.

Hartanto, W., \& Inakawati, S. (2010). Kelainan Refraksi Tak Terkoreksi Penuh di RSUP Dr. Kariadi Semarang periode 1 Januari 2002-31 Desember 2003. Media Medika Muda, $4,26-27$.

Ilyas, S. (2010). Ilmu Penyakit Mata Edisi 3. Jakarta: Balai Penerbit FKUI.

Israr, A., \& Yayan, A. (2010). Kelainan Refraksi Mata - Miopia.

Jacobi, F., \& Pusch, C. (2010). A Decade In Search Of Myopia Genes. Frontiers in Bioscience.

James, B., Chew, C., \& Bron, A. (2006). Oftalmologi Edisi 9. Jakarta: Erlangga.

Khishnaiah, S., Marmamula, S., \& Rohit, C. (2009). Prevalence and risk factors for refractive in the South Indian adult population: The Andhra Pradesh eye desease study. Clinical Ophtalmology, 3(17), 27.

Lieberman, D. (2013a). The Story of the Human Body: Evolution, Health, and Disease. New York: Pantheon Books.

Lieberman, D. (2013b). The Story Of The Human Body: Evolution, Health, And Disease. New York: Pantheon Books.

Mutia, M. (2018). Hubungan Lama Aktivitas Membaca Dengan Derajat Miopia Pada Mahasiswa Pendidikan Dokter FK Unand. E-Journal FK UNAND.

Rose, K. A., Morgan, I. G., Smith, W., Burlutsky, G., Mitchell, P., \& Saw, S. M. (2018). Myopia, lifestyle, and schooling in students of Chinese ethnicity in Singapore and Sydney. Archives of Ophthalmology. https://doi.org/10.1001/archopht.126.4.527

Sukamto, N. (2018). Hubungan Faktor Keturunan, Aktivitas Jarak Dekat, Dan Aktivitas Di Luar Ruangan Dengan Kejadian Miopia Pada Mahasiswa Fakultas Kedokteran Universitas Lampung Angkatan 2014. E-Journal UNILA.

World Health Organization. (2012). What Is A Refractive Error. Retrieved from https://www.who.int/news-room/q-a-detail/what-is-a-refractive-error

Yingyong, P. (2012). Risk Factors for Refractive Errors in Primary School Children 6-12 Years Old in Nakhon Pathom Province. J Med Assoc Thai, 93(11), 1288-1293.

Titi Lestari, eatall, Risk Factors for Myopia Abnormalities at the Bintang Amin Pertamina Hospital, jiksh Vol.11 No. 1 Juni 2020 